\title{
Automated auditory brainstem response vs. otoacoustic emissions in newborn hearing screening - prospective, pilot screening trial
}

\author{
Katarzyna Wroblewska-Seniuk', Monika Zych², Grazyna Greczka², Dobrochna Naskrecka³, \\ Franciszek Borys ${ }^{3}$, Piotr Dabrowski², Jan Mazela ${ }^{1}$
}

1 Department of Newborns' Infectious Diseases, Poznan University of Medical Sciences, Poland

2 Department of Otolaryngology and Oncological Laryngology, Poznan University of Medical Sciences, Poland

${ }^{3}$ Students' Research Circle at the Department of Newborns' Infectious Diseases, Poznan University of Medical Sciences, Poznan, Poland

\section{BACKGROUND}

$>$ Severe bilateral sensorineural hearing loss (> $50 \mathrm{~dB}$ ) affects 1-3 in 1000 live births in the normal newborn population and 2-4 in 100 infants in the intensive care population. Early diagnosis and treatment of congenital and acquired hearing impairment in newborns is a key element for optimal speech development.

$>$ The Polish Universal Neonatal Hearing Screening Program (PUNHSP) by means of transient evoked otoacoustic emissions (TEOAEs) has been carried out in Poland since 2002.

$>$ Gold standard in hearing screening - automated auditory brainstem response (AABR) - clinically proven sensitivity and specificity. It detects hearing deficit not only at the level of ear but also of neural origin.

$>$ Risk factors of hearing impairement - prematurity, treatment in the intensive care unit, mechanical ventilation, ototoxic treatment

$>$ Recent recommendations suggest implementation of AABR to newborn hearing screening, to identify the group of newborns at higher risk of hearing impairment.

\section{METHODS}

$>$ The study was performed at the University Hospital in Poznan, Poland between 01.08.2017 and 31.07.2018.

$>$ The group of 309 infants with risk factors of hearing deficit and 100 children of the control group were examined by means of both TEOAE and AABR before discharge from the hospital after birth. Healthy neonates were screened in the second or third day of life; infants treated in NICU - when their general condition was stable. All children were tested bilaterally, without any sedation, while sleeping.

$>$ Patient demographic data, risk factors of hearing loss and the results of screening were recorded in the questionnaire. The outcomes of screening were presented as 'positive' (i.e. hearing problem detected) or 'negative' (i.e. hearing problem not detected) which corresponds to 'refer' in at least one ear and 'pass' in both ears.

$>$ Infants who failed the screening test and/or had risk factors of hearing deficit were referred for further audiological evaluation within 3 months of life or immediately after hospital discharge. The results of the tests performed in the outpatient clinic were collected to assess the accuracy of the screening by means of TEOAEs and AABR.

Table 1. Number of children with specific risk factors of hearing deficit in the study group.

\begin{tabular}{|c|c|c|}
\hline Risk factor & \multicolumn{2}{|c|}{ Number of infants ( $\mathbf{n}=\mathbf{3 0 9})$} \\
\hline Treatment in NICU (>7 days) & 271 & $87.7 \%$ \\
\hline Mech. ventilation (>5 days) & 252 & $81.6 \%$ \\
\hline Ototoxic medications & 238 & $77.0 \%$ \\
\hline Prematurity (<33 Hbd) & 217 & $70.2 \%$ \\
\hline Very low birth weight (<1500 g) & 126 & $40.8 \%$ \\
\hline Low Apgar score & 54 & $17.5 \%$ \\
\hline Craniofacial congenital anomaly & 5 & $1.6 \%$ \\
\hline Family history & 4 & $1.3 \%$ \\
\hline TORCH infection & 3 & $1 \%$ \\
\hline Complex congenital anomalies & 3 & $1 \%$ \\
\hline Hyperbilirubinemia & 2 & $0.7 \%$ \\
\hline Bacterial meningitis & 1 & $0.3 \%$ \\
\hline
\end{tabular}

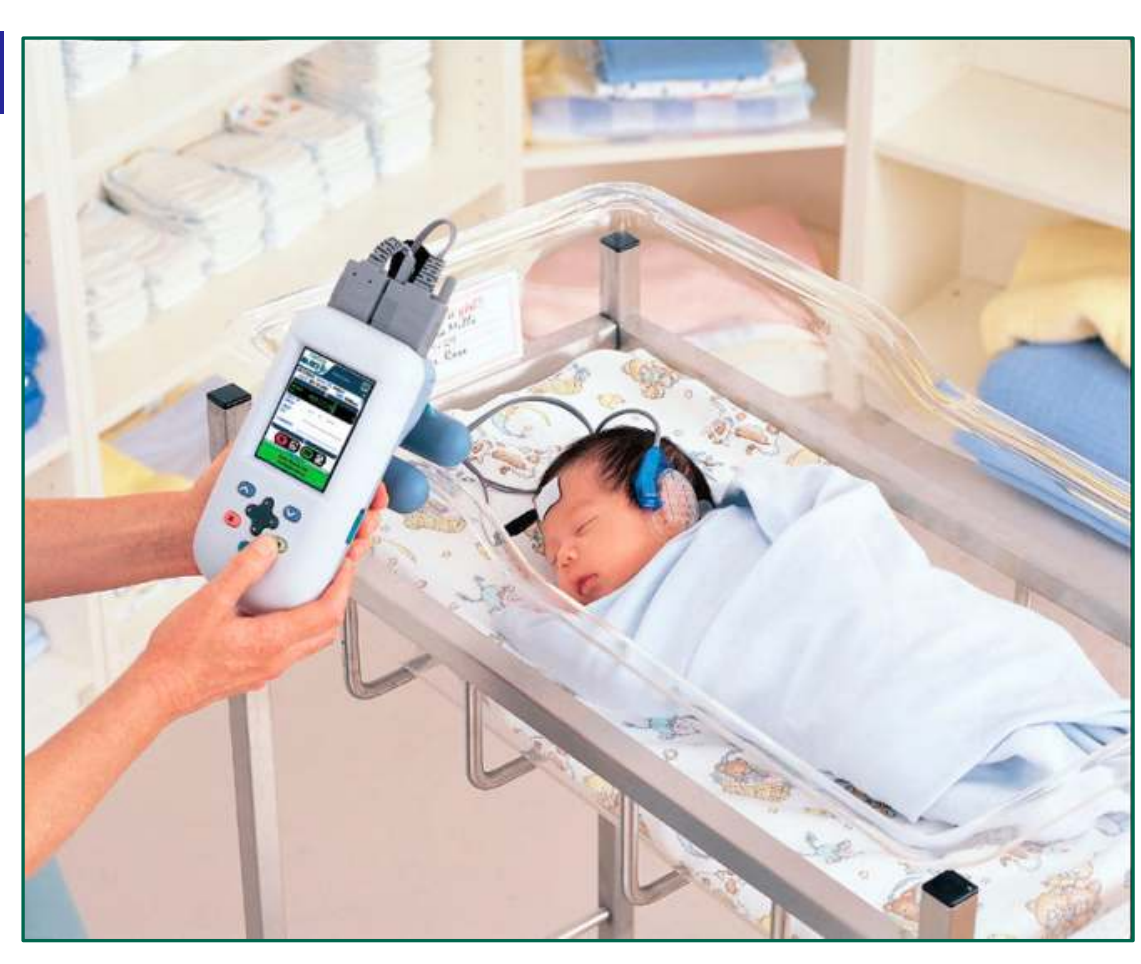

OBJECTIVE

The aim of the study was to analyze the effectiveness of OAE and AABR used as screening tools for hearing impairment among infants.

\begin{tabular}{|c|c|c|c|}
\hline \multicolumn{4}{|c|}{ RESULTS } \\
\hline Actual status of diagnosis & \multicolumn{2}{|c|}{ Number of children ( $n=309$ ) } & \multirow{5}{*}{$\begin{array}{l}\text { Table 2. The actual status } \\
\text { of diagnosis of hearing } \\
\text { impairement in the study } \\
\text { group. } \\
\text { Table } 3 \text {. False positive and } \\
\text { false negative results. }\end{array}$} \\
\hline Impaired hearing & 5 & $1.6 \%$ & \\
\hline Normal hearing & 170 & $55.0 \%$ & \\
\hline In the course of diagnosis & 75 & $24.3 \%$ & \\
\hline Lost to follow-up & 59 & $19.1 \%$ & \\
\hline
\end{tabular}

\begin{tabular}{|c|c|c|c|c|c|c|}
\hline $\begin{array}{c}\text { Screening } \\
\text { method }\end{array}$ & \multicolumn{2}{|c|}{$\begin{array}{c}\text { Positive result - } \\
\text { 'Refer' }\end{array}$} & \multicolumn{2}{c|}{$\begin{array}{c}\text { Confirmed hearing } \\
\text { deficit }\end{array}$} & $\begin{array}{c}\text { False positive } \\
\text { results }\end{array}$ & $\begin{array}{c}\text { False negative } \\
\text { results }\end{array}$ \\
\hline & Bilateral & Unilateral & Bilateral & Unilateral & & \\
\hline $\begin{array}{c}\text { OAE } \\
(\mathbf{n = 4 0 9 )}\end{array}$ & $6(1.5 \%)$ & $2(0.5 \%)$ & $4(66.7 \%)$ & $1(50 \%)$ & $\begin{array}{c}3 \\
\left(0.7 \%^{\mathrm{a}} / 37.5 \% \%^{\mathrm{b}}\right)\end{array}$ & $3\left(0.7 \%^{\mathrm{a}}\right)$ \\
\hline $\begin{array}{c}\text { AABR } \\
(\mathbf{n}=409)\end{array}$ & $9(2.2 \%)$ & $16(3.9 \%)$ & $3(33.3 \%)$ & $0(0 \%)$ & $\begin{array}{c}12 \\
\left(2.9 \%^{\mathrm{a}} / 48 \%^{\mathrm{b}}\right)\end{array}$ & $4(1.0 \% \mathrm{a})$ \\
\hline
\end{tabular}

$\mathrm{a}-\%$ of the whole group, $\mathrm{b}-\%$ of the positive results

Table 4. Risk factors and the results of hearing screening in children with the final diagnosis of hearing deficit.

\begin{tabular}{|c|c|c|c|c|}
\hline & OAE & AABR & Risk factors & Final diagnosis \\
\hline 1 & Pass/Pass & Pass/Pass & $\begin{array}{c}\text { ototoxic treatment; NICU }>7 \text { days; } \\
\text { mechanical ventilation }>5 \text { days; } \\
<1500 \mathrm{~g} ;<32 \mathrm{wg} ; \\
\text { positive family history }\end{array}$ & $\begin{array}{l}\text { bilateral, mixed type, } \\
\text { mild hearing deficit } \\
(<40 \mathrm{~dB})\end{array}$ \\
\hline 2 & Pass/Pass & Pass/Pass & $\begin{array}{c}\text { ototoxic treatment; } \mathrm{NICU}>7 \text { days; } \\
\text { mechanical ventilation > } 5 \text { days; } \\
<32 \mathrm{wg}\end{array}$ & $\begin{array}{l}\text { bilateral, mixed type, } \\
\text { mild hearing deficit } \\
(<40 \mathrm{~dB})\end{array}$ \\
\hline 3 & Refer/Refer & Pass/Pass & $\begin{array}{l}\text { ototoxic treatment; } \mathrm{NICU}>7 \text { days; } \\
\text { mechanical ventilation > } 5 \text { days; }\end{array}$ & $\begin{array}{l}\text { unilateral, conductive, } \\
\text { moderate hearing } \\
\text { deficit }(41-70 \mathrm{~dB})\end{array}$ \\
\hline 4 & Pass/Pass & Pass/Pass & $\begin{array}{l}\text { ototoxic treatment; } \mathrm{NICU}>7 \text { days; } \\
\text { mechanical ventilation }>5 \text { days; } \\
\quad<1500 \mathrm{~g} ;<32 \mathrm{wg}\end{array}$ & $\begin{array}{c}\begin{array}{c}\text { unilateral, conductive, } \\
\text { mild hearing deficit } \\
(<40 \mathrm{~dB})\end{array} \\
\end{array}$ \\
\hline 5 & Refer/Refer & Refer/Refer & cytomegalovirus infection & $\begin{array}{l}\text { bilateral, sensorineural, } \\
\text { profound hearing deficit } \\
\text { (>95 dB) }\end{array}$ \\
\hline
\end{tabular}

\section{CONCLUSIONS}

1. Although $A A B R$ is treated as gold standard in newborn hearing screening, the results of screening by means of OAE and AABR in our study seem to be comparable.

2. Larger group of infants should be examined and further analysis should be performed to formulate the final conclusions of our study.

3. Our study confirms that congenital cytomegalovirus infection may lead to profound, sensorineural hearing deficit, even if it is otherwise asymptomatic. 